Вікторія Костенко

ORCID: https://orcid.org/0000-0001-9077-2191

Олена Бєлясва

ORCID: https://orcid.org/0000-0001-9060-4753

Ірина Сологор

ORCID: https://orcid.org/0000-0001-9899-6552

DOI 10.31558/1815-3070.2020.40.2.6

УДК $811.111 .659(3)$

\title{
ГРАМАТИЧНІ ЗАСОБИ ВИРАЖЕННЯ МОДАЛЬНОСТІ В ТЕКСТАХ ПОІНФОРМОВАНОЇ ЗГОДИ НА СТОМАТОЛОГІЧНЕ ЛІКУВАННЯ
}

Розглянуто граматичні засоби вираження модальності у текстах форм поінформованої згоди на стоматологічне лікування. Жанрова специфіка таких документів визначає дійсний спосіб, теперішній та майбутній граматичні часи основними виразниками реальних та потенційно реальних модальних значень. Відношення висловлювання до дійсності збігається з відношенням суб'єкта мовлення до змісту висловлювання, тому актуалізація модальності об'єктивної реальності не потребує експлічитних засобів вираження. У межах одного висловлювання також можуть нашаровуватися різні типи модальності, що зумовлено поліаспектністю референтної ситуації отримання поінформованої згоди.

Ключові слова: жанр, поінформована згода на стоматологічне лікування, категорія модальності, граматична категорія, спосіб дієслова, час, аспект.

Значущість професійної діяльності у контексті соціальних практик зумовила потребу всебічного детального дослідження особливостей фах ового спілкування, зокрема у тих сферах, які є ключовими як для окремої людини, так і суспільства загалом. Медицина, з погляду багатьох сучасних учених (Bradby, Stearns et al, Young), належить саме до таких.

Пр офесійний медичний дискурс - це складний багатоплановий соціокультурний і лінгвістичний феномен, виникнення і розвиток якого зумовлені не л ише специфікою галузі, а й низкою морально-етичних, соціально-економічних, культурно-релігійних та інших чинників. У сучасній медичній практиці добр овільна поінформована згода на медичне втручання, тобто на застосування м етодів діагностики, профілактики або лікування, пов'язаних з істотним впливом на організм, - це документ, що надає пацієнтові інформацію пр о характер медичного втручання, відбиває основні етапи комунікації між ним та лікарем та фіксує добровільне компетентне рішення пацієнта погодитися на певне втручання чи відхилити його (Костенко, Бєляєва, Сологор). Цей документ двосторонньої дії $є$ невід'ємною частиною сучасної системи правового регулювання надання медичної допомоги та соціального забезпечення (Ліщинська, Сенюта, del Carmen, Mazur). Існує значна кількість праць українських та зарубіжних дослідників, присвячених вивченню різних аспектів поінформованої згоди, пер еважно з позицій біоетики, медичного права, історії медицини. Проте лінгвістичні аспекти цього типу медичних документів, які втілюють та відбивають складну 
мовленнєво-мисленнєву діяльність учасників у процесі створення документа та пр ийняття відповідного рішення, здебільшого залишаються поза увагою мовознавців. У цьому контексті особливо актуальними є дослідження морфологічних і граматичних явищ у комунікативному вимірі: такий підхід дає можливість пр остежити закономірності планування мовленнєвих дій для досягнення певних комунікативних цілей і вибору оптимальних мовних засобів для їхнього втілення.

Поінформована добровільна згода на медичне втручання $є$ самостійним жанром передусім професійного медичного дискурсу, що склався історично і використовується для організації, упорядкування та керування соціальними зв'язками між інститутом та суспільством, між агентом дискурсу - лікарем та клієнтом дискурсу - пацієнтом, між агентами всередині інституту та, іноді, між іншими інститутами (інститут медицини - інститут права)(Carmen, Mazur). Поінформована згода містить низку елементів, характерних для дискурсу права, оскільки є юридичним документом і може виступати основною для експер тної оцінки якості медичної допомоги, об'єктом судової експер тизи тощо. Пр агматична настанова жанру поінформованої згоди на медичне лікування полягає в обміні інформацією між агентом та клієнтом дискурсу про характер рекомендованого втручання, спричинений певним станом чи хворобою, в узгодженні та регламентації пов' язаних з цим необхідних дій з боку пацієнта, щоб спонукати його до ухвалення зваженого рішення (Костенко, Сологор 92). Процес отримання поінформованої згоди медичним закладом і прийняття рішення па цієнтом не може бути однобічно охарактеризований як «ситуація передачі інформації, або як ситуація розуміння / нерозуміння» (Милевская 91): це складна спільна дискурсивна діяльність. Тексти поінформованої згоди фіксують медич ну за своїм основним змістом інформацію, яка репрезентує спеціальні знання: пр едмет обговорення, правила та стандарти, що регулюють медичну діяльність, комунікативні установки, ролі (Поворознюк 68). Безперешкодне розуміння тексту форм інформованої згоди як пр одукту дискурсивної діяльності може посприяти ухваленню зваженого компетентного рішення з боку пацієнта. Задля цього суб'єкт мовлення вибудовує повідомлення відповідно до концептуальної моделі адресата - особи з базовою чи повною середньою освітою відповідно до Міжнар одної стандартної класифікації освіти (Barro, Lee). Вивченню ар сеналу мовних засобів, покликаних сприяти повному й безперешкодному сприйняттю па цієнтами інформації щодо лікування, присвячено небагато праць українських та зарубіжних дослідників (Поворознюк; Костенко «Жанрові параметри»).

До найважливіших мовних універсалій, комунікативно-значущих категорій дискурсу й тексту належить модальність, яка формується на рівні судження $\mathrm{i}$ актуалізується в мовленні, відбиваючи інтелектуальну та емоційно-вольову оцінку мовцями змісту висловлювання (Доценко 48). Аналіз наукової літератури говорить про надзвичайно шир оке і різноаспектне трактування цього феномена. Бачення модальності як комплексної і багатоаспектної категорії, яка активно взаємодіє з цілою системою інших функціонально-семантичних категорій мови і тісно пов'язана 3 категоріями прагматичного рівня (Арутюнова, Доценко), у якій втілюються «складні взаємовідносини між чотирма чинниками комуніка- 
ції: адресантом, адресатом, змістом висловлювання і дійсністю» (Рудоман 662), стало підгрунтям для подальшого вивчення модальності в рамках антропоцентричної парадигми, коли модальність також почали розглядати як комунікативну категорію (Ваулова, Калашнян, Lillian). За комунікативного підходу модальність трактують як різнорівневу систему вираження відношення суб' єкта мовлення до змісту його висловлювання, цільової настанови, відношення змісту висловлювання до дійсності, що визначається інтенціями суб' єкта мовлення щодо «дієвості й активізації мовленнєвої комунікації» (Петров 147). Для вираження склад ного репертуару модальних значень використовують мовні засоби різного рівня, серед яких лексичні у різних мовах описані найдетальніше.

Мета запропонованої розвідки - дослідити граматичні засоби вир аження модальності та проаналізувати їхню комунікативну зумовленість і прагматичну доцільність у текстах форм поінформованої згоди на стоматологічне лікування, оскільки без ретельного аналізу граматичного рівня тексту неможливо створити документи, які б сприяли досягненню бажаних намірів адресанта, а у разі отр имання поінформованої згоди - кооперативного результату.

Матеріалом дослідження були 60 типових форм поінформованої згоди, що їх використовують у медичних установах США, які мають ліцензію на в иконання різних видів стоматологічних послуг (New York City Metropolitan Hospital Center, Alliance for Dental Care PLLC (Rochester, NH)), а також надають страхові медичні компанії (Dentists Benefits Insurance Company (DBIC), MedPro Group). Корпус досліджуваних форм був складений з викор истанням онлайн ресурсів Open Dental Softwear, American Dental Association dental records reference, Delta Dental Incorporation.

Методи, використані в дослідженні, охоплювали лінгвістичне спостер еження, елементи дискурс-аналізу - для дослідження соціального контексту створення досліджуваного документного жанру, жанровий аналіз, спр ямо ваний на виявлення зв' язку форми і функції, що сприяє розумінню когнітивного стр уктурування інформації; морфолого-синтаксичний аналіз та комунікативно-функціональний аналіз.

Трактування тер міна «модальність» в сучасному мовознавстві надзвичайно широке. Спільним же $\epsilon$ те, що в осмисленні цього явища обов'язковим $\epsilon$ елемент оцінки інфор мації, яку повідомляють, «об'єктивно-суб'єктивований смисл пропозиції» (Palmer «Mood and Modality»).

Модальність та особливості іiї актуалізації значною мірою визначаються комунікативними намірами мовця, стилістичними, жанровими рамками. У кожному типі модальності, як зазначає Л. Шнуровська, точка зору мовця виступає в особливому аспекті актуалізації (Шнуровська 72). Отже, коли йдеться пр о відношення сказаного до дійсності, передусім мають на увазі дійсність в уявленні мовця: адресант сприймає те, що повідомляється, як реальний та вірогідний факт, на підставі того, що він знає. Адресантом форм текстів поінфор мованої згоди на стоматологічне лікування виступає колективна мовна особистість (пр ацівники галузі охорони здоров'я, юристи), чиєю головною метою $є$ інфор мувати, раціонально передати спеціальне знання. Принагідно варто зазначити, що вна- 
слідок статусної нерівності адресата та адресанта виникає комунікативна асиметрія, яка посилює комунікативну роль та соціальну відповідальність останнього.

Оцінка суб' єктом мовлення пропозиції, втіленої у висловлюванні, з погл я ду ïi істинності або фактичного статусу у загальних рисах визначають як епісте мічну модальність (Доценко, Шнуровська, Lyons, Simpson). Дж. Лайонз, зокрема, кваліфікує епістемічну модальність як «будь-яке висловлювання, в якому мовець чітко визначає пр авдивість свого висловлення, одночасно виступаючи їі гарантом» (Lyons 52). На думку Шнуровської, Рудоман, Нордлінгер, Волд, епістемічні висловлювання свідчать про ставлення суб' єкта мовлення до інфор мації, яку він повідомляє, і ступінь його відповідальності за пропозиційний зміст, що може варіювати від достовір ності, впевненості, до сумніву (Шнуровська, Рудоман, Nordlinger et al, Vold). Ситуація, за якої зміст висловлювання мовець сприймає як реальний та вірогідний факт, що відповідає об'єктивній дійсності, визначається як об' єктивно-суб' єктивована модальність (Доценко, Шнуровська, Nordlinger, Palmer «Mood and Modality», Pique-Angordans et al). Г. В. Колшанський підкреслює, що «ступінь об'єктивної достовірності висловлювання залежить від ступеня пізнання конкретного явища» (Колшанский 96). Медична інфор мація, представлена у текстах поінформованої згоди, спирається на наукове знання, факти доказової медицини і, відповідно, має «статус об' єктивної достовір ності» (Баранов 106), «об’ єктивно-модальний статус» (Шнуровська 72).

Одним із основних граматичних засобів актуалізації об'єктивної модальності є спосіб дієслова - морфологічна категорія, яка, у найзагальнішому тл умаченні, виражає відношення позначуваної ним дії до позамовної дійсності як р еальної чи ірреальної. Співвідношення модальності та способу дієслова, попри окремі грунтовні праці, залишається малодослідженим, зважаючи на складність та різноплановість у підходах до вивчення. А. П. Загнітко зазначає, що «граматичні значення способу співвідносяться з комунікативними типами мовлення. В актуально-комунікативному різновиді репрезентований індикатив, а потенційно-комунікативному - кон'юнктив та імператив, реалізація яких співвідноситься з реальністю / ірреальністю дії і типами речень за відношення м до дій сності» (Загнітко 210).

У досліджуваних текстах поінформованої згоди на стоматологічне лікування присудок, представлений дієсловом дійсного способу, виражає (стверджує або заперечує) дію, мислиму адресантом як реальну. Прикладом може бути пр актично будь-який текст у нашій вибірці: The nature of root canal therapy has been explained to me and I have had a chance to have all of my questions answered. («Root canal treatment»). These risks include possible unsuccessful results and / or failure of the filling associated with, but not limited to, the following: ... $<\ldots>$ («Composite Filling»).

Endodontic (root canal) therapy is performed in order to save a tooth which otherwise might need to be removed. This is accomplished by conservative root canal therapy, or when needed, endodontic surgery («Concent Form for Endodontic»).

Модальність також пов' язана з категорією часу (Comrie; Depraetere, Reeds; Hopper, Palmer «Mood and Modality»), яка є специфічним мовним відбиттям об' єктивного часу, що служить для тимчасової локалізації дії, про яку йдеться в 
реченні. П. Дж. Хоппер стверджує, що «в будь-якому висловленні особливе зна чення відіграє часовий контур дії та відношення до нього мовця», гр аматичн ими корелятами яких $\epsilon$ категорії часу, аспекту і модальності (Hopper 96). У досліджуваних текстах часові форми дієслів дійсного способу є важливим засобом реалізації об' єктивної модальності. Цілком передбачувано найбільш пр едста вленими виявилися дієслова в формі Present Simple, яка, на думку лінгвістів, $\epsilon$ найбільш узагальненою та немаркованою категорією (Palmer «The English verb»; Comrie; Depraetere, Reeds). Дієслова у Present Simple можуть означати теперішній актуальний, теперішній постійний або теперішній абстрактний час (П'ятничка 109) і використовуються для вираження загальних наукових фактів, релевантних для пацієнта, зокрема, напр иклад, під час опису виникнення захворювання, його пер ебігу, лікування чи профілактики, наприклад: Symptoms of TMJ associated with dental treatment are usually transitory in nature and well tolerated by most patients («General Dental Procedure»).

Для позначення теперішнього актуального часу як одного з маркерів об' $є к-$ тивної модальності у текстах поінформованої згоди також широко застосовують дієслова у формі Present Perfect, яка, на думку I. Депратере, «вказує на суттєву значимість раніше отриманих результатів, незмінну істинність чи дійсну актуальність наслідків попередніх подій, надійність висновків, які випливають 3 попередніх дій» (Depraetere «On the resultative character of present perfect»). Haприклад: My doctor has carefully examined my mouth. Alternatives to this treatment have been explained («Informed consent for Bone»). I have been educated and informed regarding the root canal treatment for which I am giving my consent ( $« \mathrm{Con}$ sent form for Endodontic»). Дієслова у фор мі Present Perfect досліджуваних текстів актуалізують важливість результатів діалогу між лікарем і пацієнтом, який передував заповненню та підписанню документа. Отже, системне вживання Present Simple та Present Perfect у текстах поінформованої згоди є імпліцитним засобом вираження об' єктивної реальної модальності.

Контекст ситуації прийняття рішення щодо лікування - це процес, більшою мір юю орієнтований на майбутнє, тому спостерігаються лише поодинокі випа дки вживання дієслів у формі Past Simple для узагальнення чи посилення об ' єктивності висловлювання: The United States Food and Drug Association, along with the manufacturer of one of these drugs (Fosamax) issued a warning to health care professionals on this issue on September 24th 2004 («General Dental Procedure»). Дієслова у формі Future Simple дійсного способу, що за уживаністю у досліджуваних текстах слідують за Present Simple та Present Perfect, використовують для позначення послідовних чи типових дій, характерних для певної ситуації, наприклад, окремих процедурних моментів: Your dentist will design a treatment plan in which he / she will recommend that you undergo specific dental procedures («Informed Consent for General Dental»). You will be presented with the optimum treatment for your particular dental needs. During the procedure, my gums will be opened to permit better access to the roots and jaw bone. Inflamed and infected gum tissue will be removed and the root surfaces will be thoroughly cleaned («Informed Consent for Crown»). 
I хоча об'єктивна реальна модальність найчастіше виражається у двох часових площинах - теперішньому і минулому, проте, як випливає з прикладів, наведених вище, майбутній час, зокрема Future Simple, також може виступати одним із засобів ії вираження, позначаючи не просто майбутню дію, а об' єктивну необхідність іiі виконання, упевненість у ії виконанні. Чергування форм теперішнього, минулого та майбутнього часу у формах поінформованої згоди також вказує на логічну послідовність подій, демонструє відповідність інформації, пр едставленої в тексті, дійсному стану речей, реальним зв 'язкам між предметами та явищами, забезпечує його зв 'язність на фактологічно-реальному рівні.

Отже, у випадках, коли відношення висловлювання до дійсності збігається 3 відношенням суб' єкта мовлення до змісту висловлення, актуалізація об'єктивності не потребує експліцитних засобів вираження: у таких висловлюваннях об' єктивність підкреслюється саме відсутністю показників упевненості / невпевненості, категоричності тощо. Побідні висловлювання оцінюють як такі, що мають «фактологічну силу впливу» на адресата (Тріщук 119), оскільки нейтральність викладу спонукає пацієнта до самостійності та відповідальності в ухваленні важливого рішення стосовно свого здоров'я.

На думку Л. С. Єрмолаєвої, «реальними виступають дії не лише такі, що здійснилися, а й такі, які відбуваються в певний відрізок часу, а також дії, р еальність здійснення яких можлива, бажана, необхідна або ж тільки пр ипускається» (Ермолаева 98). Для втілення передбачуваних дій, станів, процесів вживаються умовні речення. У текстах, що досліджувалися, для вираження закономірностей або часто повторюваних подій, що стали правилами ведення клінічної пр актики, використовують умовні речення нульового типу (Zero Conditionals): If unexpected problems arise during the procedure, the doctor has my permission to do what is deemed necessary to correct the condition («Oral Surgery»). When fillings are placed or replaced, the preparation of the teeth often requires the removal of tooth structures adequate to ensure that the diseased or otherwise compromised tooth structure provides sound tooth structure for placement of the restoration («Restorative treatment consent form»). If I fail to show up for a scheduled appointment, I take full responsibility for any serious consequences, such as hospitalization or death from infection, and hold the dentist harmless for my own acts («Root canal treatment»). У розглянутих прикладах реальна умова виражає дійсну залежність однієї дії від іншої і передбачає обов'язкове ії здійснення.

Для передачі реальної або потенційно вірогідної ситуації в теперішньому або майбутньому часі, яка найчастіше пов' язана з процедурою лікування чи можливими ускладненнями, використовують умовні речення 1 -го типу (First Conditionals): If such sensitivity is persistent or lasts for an extended period of time, I will notify the dentist because this can be a sign of more serious problems. When a composite filling is placed, effort will be made to closely approximate the appearance of natural tooth colour («Informed Consent Composite Filling»).

First Conditional з модальними дієсловами в складі присудків головної частини такожє досить вживаними в текстах поінформованої згоди на стоматологічне лікування, водночас мовець за допомогою модальних дієслів вдається до 
хеджування, відбиваючи ймовірнісний характер медичних знань: If the root canal fails, I may need additional treatment or the tooth may need to be removed («Root canal treatment»). An impacted wisdom tooth can cause a number of problems if not removed («Wisdom teeth removal»). У розглянутих прикладах за допомогою пр ийому хеджування досягають зниження категоричності висловлювання, водночас його об'єктивність зберігається. Також хеджинг є одним із засобів акту алізації епістемічної модальності, та, загалом, свідчить про складну багатошарову структуру модальності досліджуваних текстів.

Типовою ознакою жанру поінформованої згоди на стоматологічне лікування $\epsilon$ вживання Zero Conditionals, щоб надати вказівки чи інструкції пацієнтам: If there is anything raised that concerns you or you do not understand please ask or inform your operator prior to undertaking the procedure («Consent for Filling»). If you have any questions about these alternatives, or about any other treatments you have heard or thought about, please ask («Patient Consent to Begin Orthodontics»). If your procedure is being performed under general anaesthesia or sedation, do not take anymedications used to treat diabetes on the day of surgery. Ці речення мають футуральну перспективу, оскільки у них розглядаються можливі потенційні в ипадки. Умовні частини розглянутих складнопідрядних речень вказують на об' єктивну ір реальності, яка входить до поля епістемічної модальності, а головні частини виражають дію, що позначається імперативною формою, з семантичними ознаками наказу, спонукання, тобто експлікують значення модальності спонукання, яка входить до поля деонтичної модальності.

У процесі дослідження текстів поінформованої згоди заслуговує на увагу і той факт, що колективний адресант документа поінформованої згоди формує та втілює своє бачення бажаної моделі поведінки узагальненого пацієнта, створюючи окремі фрагменти тексту, створені, так би мовити, від його імені: After that, I understand that I will require a filling or a restoration which may consist of a simple filling and/or a crown («Informed Consent for Endodontic Treatment»). OTже, у таких випадках до значень об' єктивної модальності нашаровуються імпліцитні суб'єктивно-оцінні значення.

Отже, модальність текстів поінформованої згоди на стоматологічне лікування значною мірою зумовлена низкою екстралінгвістичних чинників, зокрема типом дискурсу, жанровою природою, складністю референтної ситуації, відн ошеннями між суб'єктом мовлення і адресатом та комунікативною настановою тексту. Комунікативна стратегія інформування, що є ключовою у досліджуваних текстах, охоплює сукупність мовленнєвих дій адресанта, спрямованих на подання інформації об'єктивного характеру для впливу на модель світосприйняття адресата. Медична інформація у текстах поінформованої згоди представлена як реальний та достовірний факт, що відповідає об'єктивній дійсності, спирається на наукове знання, факти доказової медицини. Для втілення намір у надати до статню і об' єктивну інформацію про стоматологічне втручання, альтернативи лікуванню, наслідки тощо суб' єкт мовлення добирає мовні засоби, які можуть не мати прямої експлікації модальності в поверхневі структури тексту. Осно вними граматичними засобами вир аження об'єктивної епістемічної модальності 
у досліджуваних текстах традиційно виступає дійсний спосіб дієслова. Модальність також пов' язана і з категорією часу, водночас найуживанішими формами $\epsilon$ Present Simple, Present Perfect та Future Simple. Оскількир еферентна ситуація має футуральну спрямованість, тому майже відсутні форми минулого часу. Для в ираження закономірностей, часто повторюваних подій, які стали пр авилами ведення клінічної практики, використовують також умовні речення нульового типу. Реальна або потенційно вірогідна ситуація в майбутньому часі, яка найчастіше пов' язана $з$ пр оцедурою лікування чи виникненням передбачуваних / непередбачуваних ускладнень, есплікується з використанням умовних речень 1 -го типу.

Характерною ознакою текстів поінфор мованої згоди є те, що у межах одно го висловлювання можуть нашаровуватися та взаємодіяти різні типи модальн ості, що, очевидно, зумовлено поліаспектністю референтної ситуації отримання / пр ийняття зваженого рішення щодо лікування, складністю спеціальної інфо р мації.

Перспективним видається дослідження модальності тексту поінформованої згоди з позиції адресата, що зумовлено відсутністю опису інтерпр етаційно го потенціалу експлікаторів модальності. Звернення до сфери документації розширює знання про професійний дискурс та дискурсивну спільноту, сприяє підвищенню ефективності професійної комунікації.

\section{Література}

1. Арутюнова Н. Д. Язык и мир человека: монографія. Москва: Языки русской культуры, 1998. $896 \mathrm{c}$.

2. Ваулова С. С. Модальность как коммуникативная категория: некоторые дискуссионные аспекты исследования. Вестник Балтийского федерального университета им. И. Канта. Серия: Филология, педагогика, психология. 2013. Вып. 8. С. 7-13. Web. 3 Sept. 2020.

3. Баранов А. Г. Функционально-прагматическая концепция текста. Ростов н/Д: Изд-во РГУ, 1993. $182 \mathrm{c.}$

4. Доценко О. Л. Семантико-прагматичний синтаксис: особливості вираження модальності: монографія. Киев: Міленіум, 2006. 226 с.

5. Ермолаева Л. С. Типология системы наклонения в современных германских языках. Вопр. языкознания. 1977. № 4. С. 97-106.

6. Загнітко А. П. Теоретична граматика української мови: Морфологія: монографія. Донецьк: ДонДУ, 1996. 435 с.

7. Калашян А. П. Коммуникативные аспекты категории модальности: автореф. дис. ... канд. филол. наук. Ереван, 1992. 22 с. Web. 18 Aug. 2020.

8. Костенко В. Г., Бєляєва О. М., Сологор І. М. Жанрові параметри англомовного документа інформованої згоди на виконання стоматологічного втручання. Наукові записки Наиіо нального університету «Острозька академія». Серія: Філологія, 2019. Вип. 6(74). С. 69-73.

9. Костенко В. Г., Сологор І. М. Актуалізація комунікативної стратегії інформування в текстах документів інформованої згоди на стоматологічне втручання. Закарпатські фiлoлогічні студї. 2019. № 7. С. 92-97.

10. Колшанский Г. В. К вопросу о содержании языковой категории модальности. Вопр. языкознания. 1961. № 1. С. 94-98.

11. Ліщинська О. І. Цінність життя як аксіологічний орієнтир етико-прикладного знання. Університетська кафедра. 2013. № 2. С. 57-73. 
12. Милевская Т. В. Дискурс, речевая деятельность, текст. Теория коммуникации и прикладная коммуникащия. Вестник Российской коммуникативной ассоциащии: сб. науч. тр. Вып. 1. Ростов-на-Дону: ИУБиП, 2002. С. 88-91. Web. 6 June 2020.

13. Петров Н. Е. О содержании и объем языковой модальности. Новосибирск: Наука, 1982. $160 \mathrm{c}$.

14. Поворознюк Р. В. Інформована згода як об'єкт перекладознавчих студій. Наукові записки Ніжинського державного університету ім. Миколи Гоголя. Філологічні науки. 2016. Кн. 2. С. 67-75. Web. 12 Sept. 2020.

15. П'ятничка Т. В. Темпоральна специфікація теперішності. Наукові записки Віннищького дер жавного педагогічного університету. Серія: Філологія. Вінниця: 2012. Вип. 15. С. 106-112.

16. Рудоман О. А. Епістемічна модальність як мовна категорія дискурсу. Молодий вчений. 2017. № 10(50). С. 660-664.

17. Сенюта I. Я. Захист прав суб'єктів медичних правовідносин: деякі теоретико-правові аспекти. Бюлетень Міністерства юстииї України. 2011. № 4. С. 11-18.

18. Тріщук О. В. Модальність реферативного тексту. Наукові записки Інституту журналістики. 2007. C. 116-122. Web. 20 Aug. 2020.

19. Шнуровська Л. Класифікація типів модальності: функціонально-семантичний підхід. Наукові записки ТНПУ. Серія: Мовознавство. 2(28), 2017. С. 70-75.

20. Barro R., Lee J.-W. 2013. Educational Attainment Dataset.17 June 2013. Web. 15 May 2020.

21. Bradby, H. Medicine, Health and Society: A Critical Sociology. SAGE Publications Ltd, 2012. $200 \mathrm{p}$.

22. Bybee J., Perkins R., Pagliuca W. The evolution of grammar: Tense, aspect, and modality in the languages of the world. Chicago: University of Chicago Press. 1994. 398 p.

23. Carmen M. G., del, Joffee S. Informed consent for medical treatment and research: a review. Oncologist. 2005. Vol. 10(8). P. 636-641. Web. 04. Feb. 2020.

24. Comrie B. Tense (Cambridge Textbooks in Linguistics). Cambridge: Cambridge University Press. 1985. $139 \mathrm{p}$.

25. Depraetere I. On the resultative character of present perfect sentences. Journal of Pragmatics, Elsevier, 1998. 29(5). Pp. 597-613. Web. 20. Aug. 2020.

26. Depraetere I., Reed S. Mood and Modality in English. The Handbook of English Linguistics. Blackwell Publishing Ltd., 2006. P. 270-290.

27. Hopper P. J. Discourse and the category Verb in English. Language and Communication. Special Issue: The Importance of Theory in Discourse Analysis. 1997. Vol. 17(2). P. 93-102. Web. 10 March 2020.

28. Lillian D. L. Modality, Persuasion and Manipulation in Canadian Conservative Discourse. Critical Approaches to Discourse Analysis across Disciplines. 2008. Vol. 2(1). P. 1-16. Web. 10. Apr. 2020.

29. Lyons J. Semantics. Cambridge: Cambridge University Press, 1977. Vol. II. 897 p.

30. Mazur D. J. Informed Consent in the Twenty First Century: What It Is, What It Isn't, and Future Challenges in Informed Consent and Shared Decision Making. Sociology Compass, 2013, vol. 7, is. 9. P. 762-774. Web. 20. Dec. 2019.

31. Nordlinger R. and Traugott E. C. Scope and the development of epistemic modality: evidence from ought to. English Language and Linguistics. 1997. Is. 1. P. 295-317.

32. Palmer F. R. The English Verb. London:Longman Group Ltd. 1988. 288 p.

33. Palmer F. R. Mood and Modality. Cambridge: Cambridge University Press, 2001. 236 p.

34. Piqué-Angordans J., Posteguillo S., Andreu-Besó J. V. Epistemic and deontic modality: A linguistic indicator of disciplinary variation in academic English. LSP \& Professional Communication. 2002. 2(2). P. 49-65.

35. Simpson P. Language, Ideology and Point of View. London: Routledge, 1993. 198 p.

36. Stearns S., Nesse R., Govindaraju D. Evolutionary perspectives on health and medicine, PNAS of the USA, 2010. 107 (suppl. 1). P. 1691-1695. Web. 15 March 2020. 
37. Vold E. T. Epistemic Modality Markers in Research Articles. Applied Linguistics. 2006. Vol. 16, № 1. P. 61-87. Web. 16. Apr. 2020.

38. Young A. The Anthropologies of Illness and Sickness. Annual Review of Anthropology. Vol. 11, 1982. P. 257-285.

\section{Список джерел}

1. Consent for Filling. https://www.halfmoondental.com/pdf/Filling\%20consent.pdf. Web. 15 Nov. 2019.

2. Consent Form for Endodontic Treatment: URL: https://www.padental.org/Images/OnlineDocs/ ResourcesPrograms/Practice\%20 Management/ConsentFormEndodontic.pdf. Web. 20 Oct. 2019.

3. Informed Consent for Bone Grafting Procedure. https://neworleansdentalcenter.com/consentforms/Consent_for_Bone_Grafting_Procedure.pdf.Web. 10 March 2020.

4. Informed Consent for Crown Lengthening Surgery: http://www.denver-perio.com/Portals/11/ Documents/P\%20CONSENT\%20CROWN\%20LENGTHENING.pdf. Web. 10 March 2020.

5. Informed Consent Composite (Tooth-Colored) Fillings. https://newtowndental.com/wp-content/uploads/2020/02/CompositeConsent.pdf. Web. 15 Nov. 2019.

6. Informed consent for composite fillings: http://absolutdent.com/wp-content/themes/biznizz/ images/pdf/Informed\%20Consent\%20for\%20Composite\%20Fillings.pdf. Web. 27 Aug. 2020.

7. Informed Consent for Endodontic Treatment. URL: https://www.endoexperience.com/filecabinet/Consent $\% 20$ Forms $\% 20$ and $\% 20$ Printouts/Consent $\% 20$ Form\%20Examples/informed $\% 20$ consent\%20double\%2004-20-02.pdf. Web. 27 Aug. 2020.

8. Informed Concent for General Dental Procedure. https://www.arlingtondentalcenter.org/wpcontent/uploads/2013/05/arlington-dental-center-new-patient-forms-2014.pdf. Web. 15 Nov. 2019.

9. Oral Surgery Patient Informed Consent. https://www.unridgedental.ca/uploads/coQwCSOJ/ ConsentforOralSurgeryFebruary2018.pdf. Web. 10 March 2020.

10. Patient Consent to Begin Orthodontic Treatment. URL: https://www.tdicinsuranentsce.com/ Portals/0/Region-D/pdfs/forms/ Orthodontic-informed-consent.pdf. Web. 10 March 2020.

11. Restorative treatment consent form. https://www.fatemifamilydentistry.com/docs/Restorative\% 20consent.pdf. Web. 27 Aug. 2020.

12. Root canal treatment and informed consent http:/theparkfamilydental.com/onlineforms/forms/ ROOTCANALTREATMENTANDINFORMEDCONSENT.pdf. Web. 27 Aug. 2020.

13. Wisdom teeth removal: written informed consent. https:/queensroaddental.co.uk/wp-content/ uploads/2017/04/QRDC-Wisdom-Tooth-Extraction-Consent.pdf. Web. 15 Nov. 2019.

\section{References}

1. Arutyunova, Nina. Yazyk $i$ mir cheloveka (Human language and world). Moskva: Yazyki russkoj kultury, 1998. Print.

2. Vaulova, Svetlana. "Modalnost kak kommunikativnaya kategoriya: nekotorye diskussionnye aspekty issledovaniya (Modality as a communicative category: some disputable issues of research)". Vestnik Baltijskogo federalnogo universiteta im. I. Kanta. (Herald of I. Kant Baltic Federal University). 8 (2013): 7-13. Web. 3 Sept. 2020.

3. Baranov, Anatoliiy. Funkcionalno-pragmaticheskaya koncepciya teksta (Functional and pragmatic conceptions of the text). Rostov n/D: Izd-vo RGU, 1993. Print.

4. Dotsenko, Olena. Semantyko-prahmatychnyi syntaksys: osoblyvosti vyrazhennia modalnosti (Semantic and pragmatic syntax). Kyiv: Milenium, 2006. Print.

5. Ermolaeva, Lubov. "Tipologiya sistemy nakloneniya $\mathrm{v}$ sovremennyh germanskih yazykah (Typology of mood system in modern Germanic languages)". Voprosy Yazykoznaniya (Topics in the study of language). (4) 1977: 97-106. Print.

6. Zahnitko, Anatoliiy. Teoretychna hramatyka ukrainskoi movy: Morfolohiia (Theoretical grammar of Ukrainian language). Donetsk: DonDU, 1996. Print. 
7. Kalashyan, Asmik. Kommunikativnye aspekty kategorii modalnosti (Communicative issues of the category of modality): Diss. Yrevan, Acharyan Language Institute. 2006. Web. 18 Aug. 2020.

8. Kostenko, Viktoriia. Bieliaieva Olena and Iryna Solohor. "Zhanrovi parametry anhlomovnoho dokumenta informovanoi zghody na vykonannia stomatolohichnoho vtruchannia (Genre parameters of documents of informed consent for dental treatment)". Naukovi zapysky Natsionalnoho universytetu "Ostrozka akademiia" (Scientific Notes of Ostroh Academy National University). 6 (74). (2019): 69-73. Print.

9. Kostenko, Viktoriia, and Iryna Solohor. "Aktualizatsiia komunikatyvnoi stratehii informuvannia $\mathrm{v}$ tekstakh dokumentiv informovanoi zghody na stomatolohichne vtruchannia (Implementation of informing strategy of communication in texts of informed consent for dental treatment)". Zakarpatski filolohichni studii (Transcarpathian philological studies). 7 (2019): 92-97. Print.

10. Kolshanskij, Hennadiiy. "K voprosu o soderzhanii yazykovoj kategorii modalnosti (To the issues on the content of linguistic category of modality)". Voprosy Yazykoznaniya (Topics in the study of language). 1 (1961): 94-98. Print.

11. Lishchynska, Olha. "Tsinnist zhyttia yak aksiolohichnyi oriientyr etyko-prykladnoho znannia (Value of the life as axiological landmark for ethic-applied knowledge)". Universytetska kafedra (University Platform). 2 (2013): 57-73. Print.

12. Milevskaya, Tatiana. "Diskurs, rechevaya deyatelnost, tekst (Discourse, speech, text)". Teoriya kommunikacii i prikladnaya kommunikaciya (Theory of communication and applied communication). Vestnik Rossijskoj kommunikativnoj associacii (Herald of Russian Comminication Association). 1 (2002): 88-91. Web. 6 June 2020.

13. Petrov, Nikolaiy. O soderzhanii i obyeme yazykovoj modalnosti (On the content and extension of language modality). Novosibirsk: Nauka, 1982. Print.

14. Povorozniuk, Roksolana. "Informovana zghoda yak obiekt perekladoznavchykh studii (Informed consent as a subject of translation studies)". Naukovi zapysky Nizhynskoho derzhavnoho universytetu im. Mykoly Hoholia. (Sientific notes of M. Gogol Nizhyn State University). 2 (2016): 67-75. Web. 12 Sept. 2020.

15. Piatnychka, Tetiana. "Temporalna spetsyfikatsiia teperishnosti (Temporal Specification of Present Tense)". Naukovi zapysky Vinnytskoho derzhavnoho pedahohichnoho universytetu (Scientific notes of Vinnytsia State Pedagogical University). 15 (2012): 106-112. Print.

16. Rudoman, Olena. "Epistemichna modalnist yak movna katehoriia dyskursu (Epistemic modality as a linguistics category of the discourse)". Molodyi vchenyi (Young scientist). 10 (50). (2017): 660-664. Print.

17. Seniuta, Iryna. "Zakhyst prav subiektiv medychnykh pravovidnosyn: deiaki teoretyko-pravovi aspekty (Protection of rights of participants in medical legal interaction: some theoretical aspects)". Biuleten Ministerstva yustytsii Ukrainy (Bulletin of the Ministry of Justice of Ukraine). 4 (2011): 11-18. Print.

18. Trishchuk, Olha. "Modalnist referatyvnoho tekstu (Modality of abstracts)". Naukovi zapysky Instytutu zhurnalistyky (Scientific Notes of Institute of Journalism). 2007: 116-122. Web. 20 Aug. 2020. Web. 20 Aug. 2020.

19. Shnurovska, Lubov. "Klasyfikatsiia typiv modalnosti: funktsionalno-semantychnyi pidkhid (Classification of the types of modality: functional and semantic approach)". Naukovi zapysky TNPU (Scientific notes of Ternopil National Pedagogical University). 2 (28). 2017: 70-75. Print.

20. Barro, Robert, and Jong-Wha Lee. Educational Attainment Dataset. 17 June 2013. Web. 15 May 2020.

21. Bradby, Hannah. Medicine, Health and Society: A Critical Sociology. SAGE Publications Ltd., 2012. Print.

22. Bybee, Joan, Perkins, Rever, and William Pagliuca. The evolution of grammar: Tense, aspect, and modality in the languages of the world. Chicago: University of Chicago Press, 1994. Print.

23. Carmen, Marcele, and Steven, del Joffee. Informed consent for medical treatment and research: a review. Oncologist. 10 (8). (2005): 636-641. Web. 04 Feb. 2020. 
24. Comrie, Bernard. Tense (Cambridge Textbooks in Linguistics). Cambridge: Cambridge University Press, 1985. Print.

25. Depraetere, Ilse. On the resultative character of present perfect sentences. Journal of Pragmatics, Elsevier, 29(5). (1998): 597-613. Web. 20 Aug. 2020. Print.

26. Depraetere, Ilse, and Susan Reed. Mood and Modality in English. The Handbook of English Linguistics. Blackwell Publishing Ltd., 2006: 270-290. Print.

27. Hopper, Paul. Discourse and the category Verb in English. Language and Communication. Special Issue: The Importance of Theory in Discourse Analysis. 17(2) (1997): 93-102. Web. 10 March 2020.

28. Lillian, Donna. Modality, Persuasion and Manipulation in Canadian Conservative Discourse. Critical Approaches to Discourse Analysis across Disciplines. 2(1). (2008): 1-16. Web. 10 Apr. 2020.

29. Lyons, John. Semantics. Cambridge: Cambridge University Press, II. (1977). Print.

30. Mazur, Dennis. Informed Consent in the Twenty First Century: What It Is, What It Isn't, and Future Challenges in Informed Consent and Shared Decision Making. Sociology Compass, 7(9). (2013): 762-774. Web. 20 Dec. 2019.

31. Nordlinger, Rahel, and Elizabeth Traugott. Scope and the development of epistemic modality: evidence from ought to. English Language and Linguistics. 1 (1997): 295-317. Print.

32. Palmer, Frank. The English Verb. London: Longman Group Ltd., 1988. Print.

33. Palmer, Frank. Mood and Modality. Cambridge: Cambridge University Press, 2001. Print.

34. Piqué-Angordans, Jordi. Posteguillo, Santiago, and J.-Vicent Andreu-Besó. Epistemic and deontic modality: A linguistic indicator of disciplinary variation in academic English. LSP \& Professional Communication. 2(2). (2002): 49-65. Print.

35. Simpson, Paul. Language, Ideology and Point of View. London: Routledge, 1993. Print.

36. Stearns, Stephen, Nesse, Randolph, and Diddahally Govindaraju. Evolutionary perspectives on health and medicine, PNAS of the USA, 107 (suppl. 1). (2010): 1691-1695. Web. 15 March 2020. Print.

37. Vold, Eva. Epistemic Modality Markers in Research Articles. Applied Linguistics. 16(1). (2006): 61-87. Web. 16 Apr. 2020.

38. Young, Allan. The Anthropologies of Illness and Sickness. Annual Review of Anthropology. 11 (1982): 257-285. Print.

\section{List of Sources}

1. Consent for Filling. https://www.halfmoondental.com/pdf/Filling\%20consent.pdf. Web. 15 Nov. 2019.

2. Consent Form for Endodontic Treatment: URL: https://www.padental.org/Images/OnlineDocs/ ResourcesPrograms/Practice\%20Management/ConsentFormEndodontic.pdf. Web. 20 Oct. 2019.

3. Informed Consent for Bone Grafting Procedure. https://neworleansdentalcenter.com/consentforms/Consent_for_Bone_Grafting_Procedure.pdf.Web. 10 March 2020.

4. Informed Consent for Crown Lengthening Surgery: http://www.denver-perio.com/Portals/11/ Documents/P\%20CONSENT\%20CROWN\%20LENGTHENING.pdf. Web. 10 March 2020.

5. Informed Consent Composite (Tooth-Colored) Fillings. https://newtowndental.com/wp-content/uploads/2020/02/CompositeConsent.pdf. Web. 15 Nov. 2019.

6. Informed consent for composite fillings: http://absolutdent.com/wp-content/themes/biznizz/ images/pdf/ Informed\%20Consent\%20for\%20Composite\%20Fillings.pdf. Web. 27 Aug. 2020.

7. Informed Consent for Endodontic Treatment. URL: https://www.endoexperience.com/filecabinet/Consent $\% 20$ Forms\%20and\%20Printouts/Consent\%20Form\%20Examples/informed\%20consent\%20double\%2004-20-02.pdf. Web. 27 Aug. 2020.

8. Informed Concent for General Dental Procedure. https://www.arlingtondentalcenter.org/wp-content/uploads/2013/05/arlington-dental-center-new-patient-forms-2014.pdf. Web. 15 Nov. 2019. 
9. Oral Surgery Patient Informed Consent. https://www.unridgedental.ca/uploads/coQwCSOJ/ ConsentforOralSurgeryFebruary2018.pdf. Web. 10 March 2020.

10. Patient Consent to Begin Orthodontic Treatment. URL: https://www.tdicinsuranentsce.com/ Portals/0/Region-D/pdfs/forms/ Orthodontic-informed-consent.pdf. Web. 10 March 2020.

11. Restorative treatment consent form. https://www.fatemifamilydentistry.com/docs/Restorative\% 20consent.pdf. Web. 27 Aug. 2020.

12. Root canal treatment and informed consent http://theparkfamilydental.com/onlineforms/ forms/ROOTCANALTREATMENTANDINFORMEDCONSENT.pdf. Web. 27 Aug. 2020.

13. Wisdom teeth removal: written informed consent. https:/queensroaddental.co.uk/wp-content/ uploads/2017/04/QRDC-Wisdom-Tooth-Extraction-Consent.pdf. Web. 15 Nov. 2019.

\section{GRAMMATICAL DEVICES FOR EXPRESSING MODALITY IN TEMPLATES OF INFORMED CONSENT FOR DENTAL TREATMENT}

Viktoriia Kostenko

Department of Foreign Languages with Latin and Medical Terminology, Ukrainian Medical Stomatological Academy, Poltava, Ukraine.

\section{Olena Bieliaieva}

Department of Foreign Languages with Latin and Medical Terminology, Ukrainian Medical Stomatological Academy, Poltava, Ukraine.

\section{Iryna Solohor}

Department of Foreign Languages with Latin and Medical Terminology, Ukrainian Medical Stomatological Academy, Poltava, Ukraine.

\section{Abstract}

Background: There have been few reports clarifying the selection of the language devices and paraverbal means in order to facilitate patients' complete and unhindered comprehension of the information in informed consent template for dental treatment and to influence them in making right decision. Modality, being one of the main linguistic universals, an anthropocentric category, plays an important role in text generation: derived from the jud gment on based on conceiving or imagining a situation, it is then expressed though the language, and reflects intellectual, emotional, and volitional evaluation whether the he premises are justified.

Purpose: to study grammatical devices for modality expression in the informed consent templates and to analyze their communicative role. 60 original templates used as research material were retrieved from the sites of the USA healthcare settings authorized to provide oral and dental services.

Results: The modality of the texts studied is considerably predetermined by the number of extralinguistic factors, including the discourse type, genre nature, complexity of the reference situation, the relationship between the addressor and addressee, and communicative purposes of the text. Informing is the key communication strategy of the texts that implies the selection of addressor's speech actions aimed to provider the addressees with sufficient and objective information thus influencing their world view and enabling them to make a decision. To realize this intention, the addressor selects language tools that may not directly explicate the modalities in the structures of the text. The indicative mood has been found out as the most typical grammatical means to express epistemic objective modality in the texts studies. Tense and aspect can also be used to express modal meaning of epistemic objective modality, and Present Simple, Present Perfect and Future Simple are the most extensively exploited tense forms. Since informed consent for dental treatment is future-oriented, the Past Simple is rarely used. Zero Conditionals express regularities, frequent found as quite frequent are used to denote recurrent events becoming the rules of clinical practice. The actual or potentially probable situation in the future, which is most often related to the treatment procedure or the occurrence of foreseeable / unforeseen complications, is expressed by First Conditionals.

Discussion: The study has demonstrated that different types of modality can overlap within one statement that is due to the multidimensional nature of the reference situation and the complexity 
of special medical information. Studying the modality of the informed consent templates from the position of the addressee seems to be promising because of the scanty reports on the interpretive potential of the modality markers.

Keywords: genre, informed consent for dental treatment, category of modality, grammatical category, mood, aspect, tense.

Vitae. Viktoriia Kostenko is a Candidate of Philology, Associate Professor, Associate Professor of Department of Foreign Languages with Latin and Medical Terminology at Ukrainian Medical Stomatological Academy. Her areas of research interests include professional communication, professional discourse (dentistry), medical terminology, issues on academic literacy and academic writing, ESP teaching.

Correspondence: viktoriakost20@ gmail.com

Vitae. Olena Bieliaieva is a Candidate of Pedagogical Sciences, Associate Professor, Head of Department of Foreign Languages with Latin and Medical Terminology at Ukrainian Medical Stomatological Academy. Her areas of research interests include pedagogy of higher education, theory of communication, quality of medical educational system, linguodidactics, terminology studies, history of medicine.

Correspondence: elenablanch69@ gmail.com

Vitae. Iryna Solohor is a Candidate of Philology, Associate Professor, Associate Professor of Department of Foreign Languages with Latin and Medical Terminology at Ukrainian Medical Stomatological Academy. The scope of her research interests includes professional discourse (German language), linguistics of the text, terminology studies, linguodidactics, teaching Latin for Special Purposes (medicine).

Correspondence: plantagoalpina@gmai.com

Надійшла до редакціії 28 вересня 2020 року. Рекомендована до друку 19 жовтня 2020 року. 